\title{
Article
}

\section{The Power of Deficit Discourses in Student Talk about Writing}

Shurli Makmillen

Clafin University

Kim Norman

University of Fraser Valley

\section{Abstract}

Does engagement with writing centre consultants in one-on-one consultations help students shift from remedial discourses toward meta-cognitive awareness more in keeping with the nature of peer review in an academic setting? This study investigates this question through looking longitudinally over a four-year period in a Canadian university writing centre. We situate this research within wider discussions of Standard English and remediation in student academic writing, as well as writing centre research that explores correlations between numbers of writing centre visits and both students' confidence as writers and their intrinsic motivation. Using a corpus-supported genre and discourse analysis, we focus on student appointment requests, as well as summative writing centre consultant notes. Results suggest that deficit discourses are highly tenacious, which we explain in part as the result of the constraints inherent in the genre of requests for help, and also in terms of the institutional positioning of writing centres.

Key Words: academic discourse; genre; grammar; writing centers/centres; discourse analysis; Bourdieu; writing remediation; writing studies

\section{Introduction}

Those of us who work with first-year students on their writing are not surprised when, at the beginning of their university degrees, students' talk is steeped in remedial discourses about grammar and self-deprecating remarks about writing abilities. It might be said that they have internalized the popular discourses about "bad writing" that are a focus of much study in our field (Cameron, 1995; Charney, Newman, \& Palmquist, 1995; Milroy \& Milroy, 1985; Rea, 2006). Nonetheless, we also pro- 
Volume 29, 2019

http://journals.sfu.ca/cjsdw

ceed in our teaching with the hope that engagement with alternative discourses-through writing centre visits and in first-year writing courses-would lessen such talk in favour of more productive stances toward their writing, reflecting meta-cognitive processes that are in keeping with the nature of peer review in an academic setting. In this study, we seek to explore this issue using data collected in one of these settings: a university writing centre. We wanted to know if repeated oneon-one writing centre consultations over the course of students' degrees have the effect of fuelling changes in their talk about writing.

To conduct our exploration, we collected four years of student requests for appointments in a writing centre from a mid-sized Canadian teaching university. When analyzed both qualitatively and quantitatively, this data throws light on the relationship between frequency of writing centre appointments and the incidence of deficit discourses, showing both promising and disappointing trends. Our results suggest that deficit discourses are highly tenacious, signalling a state of affairs that ties to both the institutional positioning of writing centres in the university, and, more largely, the continuation of current traditional approaches to writing instruction in classrooms. A secondary claim concerns the nature of the request-for-an-appointment genre in university writing centre practice: protocols asking students what they want to work on create a dysfunctional genre, further solidifying deficit discourses surrounding both student writing and writing centres.

\section{Background: The "Linguistic Market"}

Students attending contemporary universities are driven by the promise of economic mobility in job markets where the ability to write well is tantamount to success (Washington, 2014). Writing centre advocates may confess to sometimes drawing from and even proselytizing this market logic in our conversations with administrators and in our teaching, without the critical awareness we ourselves attach to it in other settings, such as this one of publication. Our critiques of this discourse may begin, for example, with French sociologist Pierre Bourdieu (1991), who notes how power is accrued to speaking subjects according to their credentials within a "linguistic market" (p. 53); dialects and styles, he pointed out, are ranked according to their deviations from "the standard" in ways that maintain relations of linguistic domination. Our critique would also acknowledge how educational institutions and labour markets are in dialectical relationship to maintain this status quo. Within this context, many have noted how writing centres can be a locus for resistance and empowerment, for the democratization of knowledge, and for epistemological access for nonmainstream (e.g. first in family, Indigenous students, non-traditional or disadvantaged students) for 
Volume 29, 2019

http://journals.sfu.ca/cjsdw

whom barriers may exist in their access to academic capital (Makmillen, Aubé \& Fitzgerald, 2013; McNamee \& Miley, 2017). Lastly, much has been written about how a current-traditional approach to the teaching of writing, which "confines writing instruction to the 'mechanical' issues of form and style that are 'learnable'” (Charney et al., 1995, pp. 299-300)1', is still a feature of some writing courses, and, as our experience in writing centres bears out, can be the de-facto approach in the assignment and assessment of writing across the undergraduate curriculum (Griffin \& Glushko, 2016, p. 168). As Dunn (2017) explains, "So convinced is the general public that young writers are in desperate need of old-fashioned, rigorous grammar, that writing teachers from grade school through grad school continue to be pressured to teach grammar as a way to improve writing" (p. 145).

To posit a writing centre as a fix-it stop, functioning only to "remediate deficient students," rather than as a site to support "students' disciplinary learning and development" (Graves, 2016, p. 6), is to undermine writing centre efforts to empower all students to succeed. And if all students are not empowered to succeed, then the status quo remains, as those who already have capital in the linguistic market have protected their investment. The dominant form of academic discourse maintains its value, after all, from its scarcity (Bourdieu, 1991). Interestingly, the phrase "academic discourse" itself originated in Bourdieu's work with this critical perspective attached: "Academic discourse, through its hierarchy of formal criteria, favours students from bourgeois backgrounds who rediscover in its medium their natural linguistic milieu, and sets further obstacles in the path of working-class students" (Bourdieu \& Passeron, 1994, p. 87). It is with this critical perspective attached that we use the term "discourse" in our analysis.

With a view to creating emancipatory conditions for students with all of the "experiences, identities, and ways of knowing that come through our door" (McNamee \& Miley, 2017, para. 5), resistance to deficit discourses has a long history in our field. Whitted (1966), in an early example, invited us to see the student as "not someone who fails to reach a mythical arbitrary standard of excellence, but is a non-member of an 'in' group with respect to communication in an academic context" (as cited in Carino, 1995, p. 109). Still, the deficit model holds on tenaciously in talk about writing, and in some writing pedagogies, despite what we know about how focusing on error in student writing fosters passivity in students (Lee, 2004; Shaughnessy, 1977). In turn, these individuals, are more likely to see their writing centre visit as a "fix it stop" for their grammar errors. Charney et al. (1995) speculate that this passivity is associated with "viewing writing ability as a lump-sum allotment or gift [which] may discourage students from investing much effort into learn- 
Volume 29, 2019

http://journals.sfu.ca/cjsdw

ing to write" (p. 300). How, then, can we in writing centres measure our efficacy in turning this passivity into an active engagement in discourse that leaves students with agency over their writing?

Much of the quantitative research on writing centres that seeks to answer such questions has been based on student survey data. Carino and Enders (2005) identify a correlation between numbers of writing centre visits and both students' confidence as writers, and their perceptions of their own ability, while Robinson (2009) considers the relationship between repeat writing centre visits and a corresponding increase in students' intrinsic motivation. We want to extend this research by treating what students say-in our case in their requests for writing centre appointments-as discourse, rather than as self-evident data. Defining discourse analysis as a "critical stance towards taken-for-granted knowledge, and a skepticism towards the view that our observations of the world unproblematically yield its true nature" (Gill, 2000, p. 173), we seek a tacit assumption underlying students' explanations for why they might seek an appointment. With this definition of discourse analysis in mind, we explore whether repeated writing centre consultations fueled, for students, more empowering, less remedial articulations of their writerly needs and challenges, longitudinally.

Artemeva's (2011) is one of the few studies we know of that take a longitudinal approach to outcomes for writing pedagogies, based on the concept of genre acquisition and using student talk about their writing. Her study of one student, Rebecca (a pseudonym), in a first-year Engineering Communications course shows that the student's initial expectations and final experience of the course were both rooted in the key term grammar. On the first course, Rebecca indicated that she "considered creativity her main strength and grammar, her weakness" (Artemeva, 2011, p. 324), and on the end-of-course survey about the course's usefulness, “Rebecca wrote 'No,' adding 'I didn't find that my grammar and language approved [sic] at all during the course"” (p. 324). Both comments suggest she saw writing instruction in terms of a focus on lower order concerns (LOCs). It was not until one term after the end of the course, in a follow-up questionnaire, that Rebecca admitted to the course's usefulness. She did so then without any reference to grammar by noting how the course provided a "basis of knowledge" for the reports she was writing in second year (p. 325). She also noted that the course provided a foundation for her workplace writing, once she recognized the degree to which writing would be a part of her employment as an engineer. In Mina Shaughnessy's (1977) terms, Rebecca finally began to see her writing as creating meaning for readers, and not as an end unto itself.

Mackiewicz (2018) also reports on a longitudinal study in her Writing Centre Talk Over Time, an analysis of transcripts of writing centre consultations, comparing student and tutor talk in 2000 
Volume 29, 2019

http://journals.sfu.ca/cjsdw

with that in 2017. Findings reveal shifts in discourse that she suggests come from both an increase in quantity and quality of tutor training, and an increase in diversity of the student body in the form of international students, many of whom were non-native speakers of English. This increase in numbers of international students is a feature of the 21st-century university, and the university in this study was no exception. Although statistics on native speaker status were not collected at this particular institution, usually between 10 and 12 percent of students were at the time international. Mackiewicz points out that talk about LOCs in a context in which "lore" about a preference for higher order concerns (HOCs) dominates could reflect this student body, as well as tutors' more generalized abilities to respond to the rhetorical situation in nuanced ways. She cautions too that an "unwavering attachment to focus on HOCs limits options and ignores the reality in which student writers live" (p. 27). While interesting and important, these contingencies concerning non-native speakers of English and what should or should not happen in consultations do not detract from our overall focus on the relationship between remedial discourses and a widened more empowered stance towards writing in the university.

Our project seeks to continue the lines of research outlined above by investigating the relationship between numbers of appointments and students' accounts of why they sought those appointments, which, regardless of students' first language statuses, can enable us to posit a claim about shifting talk about writing. While these accounts are written in the form of students' answers to the question, "What would you like to work on?" in an appointment booking system, we use the term "talk" to align ourselves with computer-mediated conversation (CMC) scholars who, like Herring (2010), see much of our online written communication as more interactive than edited, more like an email than an essay, and therefore more like conversation than writing. A student's response to the question, then, is a turn at "talk," which also anticipates a continued conversation in the writing centre visit. In terms supplied by Herring, “CMC is 'talk' and 'conversation'” (p. 7, emphasis in original).

In Researching the Writing Centre, Babcock and Thonus (2012) argue that writing centre research needs to move beyond "lore" and "anecdote" (p. 20), towards accumulating evidence-based, replicable, aggregable data (RAD). While keeping cognizant of critiques of this turn toward evidence-based practice (EBP)—for example that it is responding to a "climate in which clients demand that their needs and wants be fully met, while practitioners are increasingly concerned simply with protecting themselves from likely criticism" (Hammersley, as cited in Babcock \& Thonus, 2012, p. 39) — theirs is a "a (cautious) argument for EBP research in the Writing Centre" (Babcock 
Volume 29, 2019

http://journals.sfu.ca/cjsdw

\& Thonus, 2012, p. 31). They say adopting and adapting quantitative and qualitative methods from other fields will legitimize "writing centre studies" and make our research valid elsewhere as part of a "cross-disciplinary research tradition" (p. 31). It is with some irony we realize that on the one hand we are providing a model for such studies, one which utilizes a much-used appointment booking software (WCOnline), on the other hand we are arguing in part that the genre of student requests for an appointment dysfunctional.

\section{Method}

The project involves a discourse analysis of four years of student requests for appointments at a Canadian university writing centre. We focus primarily on the language used by students to explain their need for an appointment, as well as summative notes made after the appointment by writing centre consultants. In our corpus, we included only those students who used the centre four or more times over the course of their years at the university because we were looking for shifts in talk about writing. Nonetheless, our first run through the data simply counted the percentages of key terms used in students' responses to the question, "what do you want to work on today?" If they used terms such as "grammar," for instance, we assumed a link between the talk about grammar and remedial or deficit discourses that foster disempowering attitudes towards one's own and others' writing. We are not alone in making this connection; Griffin and Glushko (2016) also report on a pilot study in which "38\% of students used words like "' fix,' 'error,' and 'correct,"' signalling an approach to writing that focuses on "perceived deficiencies" (p. 168) that work to stigmatize, in their case, African American students for their vernacular language use.

We also did overall counts using Pennebaker's (2011) distinction between content words, i.e. those words that "express substantive properties of things and events in the world" (2), and function words, i.e. those "pronouns, articles, prepositions, conjunctions, auxiliary verbs, negations, and many common adverbs" that hold everything else together (p. 2), so that we could compare student discourse with that of faculty consultants.

Finally, to better understand our data from a qualitative perspective, we examined the full consultation records of 62 frequent users of the writing centre over a four-year period. We pulled these records from students whose number of total visits ranged from eight to 42 , with each set of visits occurring over multiple semesters. While Tan (2009) reminds us that "return or repeated visits to the writing centre can be a cause of concern too as compared to zero or few visits...[t]oo many repeated visits might indicate that the student has become over-dependent on the writing centre, 
Volume 29, 2019

http://journals.sfu.ca/cjsdw

when s/he should have built up the confidence and competence to be able to work independently" (p. 52), we hold it is impossible to determine an optimal number of visits for any given individual over a span of many terms, many different courses, and many different writing experiences. That said, the data we drew from for this analysis does represent, in various cases, some extreme use, with the most "enthusiastic" of users - two of them - each visiting 40 and 45 times over four years, respectively. No other frequent users matched these records, with 15.6 being the average number of visits per user over four years and a varied number of terms.

To conduct our analysis, we began by looking for discursive persistence in LOCs throughout user records, as signalled by written requests for consultations focused on such issues as "grammar," APA / MLA / Chicago / ASA," "spelling," and "punctuation." As mentioned, requests featuring these lower-order terms (and ones like them) were, for this study, deemed suggestive of a deficit discourse motivating and shaping users' perceptions of their work. HOCs were signalled by requests featuring terms like "ideas," “coherence," "structure," "citation," and "development." All examples of persistence in requests for LOCs, even if they were in combination with other requests, were counted as such. When LOCs progressed to HOCs over a course of visits (or conversely regressed, which did occur in three cases), this was also observed, as was discursive incongruence between user requests and related post-appointment reports written up by writing centre consultants.

\section{Results and Discussion}

An initial pass through the data did seem to reveal that disempowering discourses (signalled through the use of the term "grammar") accumulate in written requests for writing centre help made by students in applied programs, as seen in Figure 1. The results for the ESL ${ }^{2}$ Writing and Grammar category are self-explanatory, given the description of the area, which consists of two bridging courses for students needing English language support planning to enter academic programs.

The traditional disciplines of History, English, and Philosophy rank lowest in grammar talk. If we forge the link between the talk about grammar, remedial and deficit discourses, and disempowering attitudes towards one's own and others' writing, it does seem that these disempowering discourses accumulate around students who are drawn for more pragmatic reasons towards applied programs. Nursing students are interesting: their grammar is not typically "bad" at all, though they use the term a lot. They are certainly diligent about correctness in format and APA citation styles ${ }^{3}$. This diligence could be related to the gendering of this discipline, and to the real life and death need for 
Volume 29, 2019

http://journals.sfu.ca/cjsdw

attention to detail in the field in general. Anecdotally, we have heard this link between attention to the details of usage and the care in following medical protocols being forged, and so this aspect of their profession is of a heightened concern in their discipline.

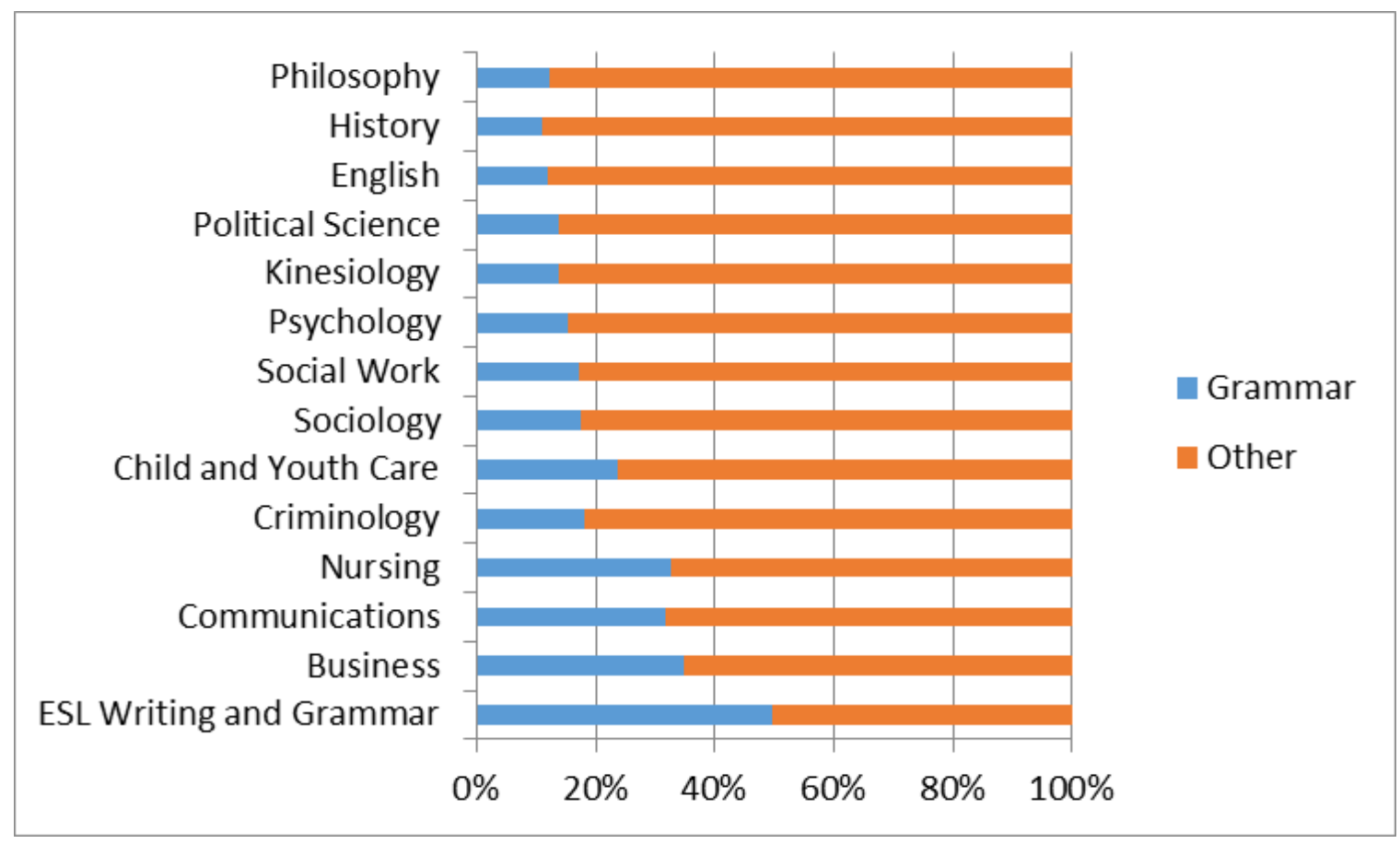

Figure 1. Percentage of students' written requests that mention grammar.

These calls for grammar might be easily read at face value, except for an overriding feature of writing centre consultant notes that revealed a sense of incongruity between what individual students said they wanted and what actually happened in the consultations:

It blows me away that this person said grammar in her "what you want to work on." It is such an ingrained response-she wanted to know what a field study was and what each part does and how to report methods and procedures. (Writing Centre Consultant)

[This student] claimed in his appointment form that he wanted to "correct grammar," but what happened in our time together wasn't that at all. We had a conversation about Swift's 'A Modest Proposal' in which [he] was able to interpret the satire and make connections to similar satirical stories he had heard in China. In other words he understands the big picture; the 
Volume 29, 2019

http://journals.sfu.ca/cjsdw

next stage is linking the content of one paragraph of the "proposal" to these larger concerns.

(Writing Centre Consultant)

This incongruity will not be a surprise to anyone who has worked in a writing centre, and in many ways seeking to understand this very phenomenon was the impetus for our study: it led us to trace both qualitatively and quantitatively the shifts in individual student requests. Following an individual student through two semesters, for example, reveals how their request language shifts in relation to consultant categories and comments.

This incongruity inspired us to look more systematically at correlations between students' requests and consultant notes, to represent two trends in students' writing centre visits through their four-year degrees (see Table 1 and Table 2).

Table 1.

One student's writing centre help requests and subsequent consultant comments over one year

\begin{tabular}{|c|c|c|c|}
\hline Date & Course & $\begin{array}{l}\text { What would you like to work on } \\
\text { today? }\end{array}$ & $\begin{array}{l}\text { Consultant categories }{ }^{* * *} \text { and com- } \\
\text { ments }\end{array}$ \\
\hline 19-Sep-13 & $\begin{array}{l}\text { Philosophy (1st } \\
\text { year) }\end{array}$ & $\begin{array}{l}\text { My wording, English is my second } \\
\text { Language }\end{array}$ & $\begin{array}{l}\text { All (brainstorming and working with } \\
\text { details and abstract categories) }\end{array}$ \\
\hline 03-Oct-13 & CMNS* $^{*}$ & paraphrasing & Details/descriptions/examples \\
\hline 10-Oct-13 & CMNS & Just need help & $\begin{array}{l}\text { practising for an in-class writing [as- } \\
\text { signment] }\end{array}$ \\
\hline $31-0 c t-13$ & Social Work & I need help proof reading & Identifying position \\
\hline $\begin{array}{l}\text { 06-Mar- } \\
14\end{array}$ & $\mathrm{SOC}^{* *}(2$ nd year) & $\begin{array}{l}\text { I need someone to help go through } \\
\text { my work. }\end{array}$ & $\begin{array}{l}\text { All (sentence level grammatical and } \\
\text { lexical concerns) } \\
\text { I don't think our extended focus on } \\
\text { punctuation is going to have any lasting } \\
\text { effects }\end{array}$ \\
\hline $\begin{array}{l}\text { 18-Mar- } \\
14\end{array}$ & CMNS (2nd year) & $\begin{array}{l}\text { I need a second reader for my as- } \\
\text { signment. }\end{array}$ & $\begin{array}{l}\text { Genre-specific concerns } \\
\text { All (brainstorming and working with } \\
\text { details and abstract categories) }\end{array}$ \\
\hline
\end{tabular}

Note: Comments and course descriptors have been reproduced exactly as written on the assignment request forms. ${ }^{*}$ Communications, ${ }^{* *}$ Sociology, ${ }^{* * *}$ Categories come from a drop-dwon menu created on WC Online and comments are the instructors' own words.

Looking at Table 1 from top to bottom, we see that the student eventually landed on language that avoids sentence-level proofreading, and also finally reflects the categories set up on the writing 
Volume 29, 2019

http://journals.sfu.ca/cjsdw

centre's booking system software, and the consultants' written comments. In the first four appointments, the focus was on HOCs (e.g., working with abstractions and details), despite the LOCs in the first and fourth request for an appointment. The fifth appointment focused on punctuation, but not in a way that the consultant deemed as transferable. Finally, the consultant comments are congruent with the last appointment request for "a second reader," and what we know about the writing process when students have a keener sense of their writing as "genre-specific."

Table 2. A second student's writing centre help requests and subsequent consultant comments over one year

\begin{tabular}{|c|c|c|c|}
\hline Date & Course & $\begin{array}{l}\text { What do you want to } \\
\text { work on today? }\end{array}$ & Consultant categories and comments \\
\hline 22-Sep-11 & psychology 101 & $\begin{array}{l}\text { i would like to go through } \\
\text { the summary that i have } \\
\text { written, and get help with } \\
\text { making it better and mak- } \\
\text { ing sure it is what my in- } \\
\text { structor will like. }\end{array}$ & $\begin{array}{l}\text { All of the above } \\
\text { Scholarly summary in all its permutations. }\end{array}$ \\
\hline 28-Sep-11 & history arts & \begin{tabular}{|l|} 
I would like to go over the \\
one i have already typed \\
out, and get help seeing \\
what could make the essay \\
better.
\end{tabular} & $\begin{array}{l}\text { topic narrowing establishing significance of top- } \\
\text { ic and identifying position. } \\
\text { the anxieties of the newness made for some in- } \\
\text { terruptions of understanding but moving for- } \\
\text { wards! }\end{array}$ \\
\hline 09-Nov-11 & History 101 & \begin{tabular}{|l|} 
would like to go through \\
and help out some of the \\
problems i had faced with \\
my other assignment. \\
Would like to see how i can \\
improve my grade \\
\end{tabular} & $\begin{array}{l}\text { All (brainstorming and working with details and } \\
\text { abstract categories) } \\
\text { [Student] was well into writing and thinking } \\
\text { through her ideas. I think this consultation } \\
\text { demonstrated to both of us how writing and } \\
\text { thinking go hand in hand. }\end{array}$ \\
\hline 06-Feb-12 & English 105 & \begin{tabular}{|l|} 
Just having someone look \\
over it ! and help me see if I \\
am missing anything or I \\
need to add anything.
\end{tabular} & $\begin{array}{l}\text { Abstractions/definitions/naming/categorization } \\
\text { [Student] wanted to get a sense of whether a } \\
\text { reader could follow the development of the rea- } \\
\text { soning in her paper. We also talked about schol- } \\
\text { arly conclusions...about considering implications } \\
\text { of our previous discussion. }\end{array}$ \\
\hline 21-Mar-12 & MATH 105 & \begin{tabular}{|l|} 
Just have another person \\
look it over and help me see \\
what I can improve.
\end{tabular} & \begin{tabular}{|l|} 
Details/descriptions/examples \\
Summary features: appropriateness of organiza- \\
tion, coverage, paraphrasing strategies, framing. \\
\end{tabular} \\
\hline 04-Apr-12 & Hist 102 & $\begin{array}{l}\text { Would like to go over this } \\
\text { assignment once more to } \\
\text { check for errors and ways } \\
\text { to improve it and make it } \\
\text { flow. }\end{array}$ & $\begin{array}{l}\text { All (brainstorming and working with details and } \\
\text { abstract categories) } \\
\text { Consistency and coherence of summary; some } \\
\text { micro-level issues }\end{array}$ \\
\hline
\end{tabular}


Volume 29, 2019

http://journals.sfu.ca/cjsdw

Table 2. (Continued)

\begin{tabular}{|c|c|c|c|}
\hline $25-0 c t-12$ & $\begin{array}{l}\text { human develop- } \\
\text { ment }\end{array}$ & $\begin{array}{l}\text { Go over it and } \\
\text { hopefully help to } \\
\text { improve it. }\end{array}$ & $\begin{array}{l}\text { Identifying position } \\
\text { [Student] was doing some good work on a re- } \\
\text { search paper that looks at the possible benefits } \\
\text { of breast feeding...she really got the idea that the } \\
\text { research was quite mixed, and though she want- } \\
\text { ed to argue for clear benefits of breast feeding } \\
\text { for children's intellectual development, that she } \\
\text { also needed to fairly represent the state of } \\
\text { knowledge. }\end{array}$ \\
\hline $14-N o v-12$ & ECE $^{*} 100$ & $\begin{array}{l}\text { Go through and } \\
\text { check for gram- } \\
\text { mar. }\end{array}$ & $\begin{array}{l}\text { Details/descriptions/examples } \\
\text { proofreading strategies }\end{array}$ \\
\hline 06-Mar-13 & Intro to ECE & $\begin{array}{l}\text { Just go over } \\
\text { spelling and } \\
\text { structure. }\end{array}$ & Assignment/consultant expectations \\
\hline 25-Jul-13 & $\mathrm{HSER}^{* *} 120$ & Fix my grammar. & Abstractions/definitions/naming/categorization \\
\hline
\end{tabular}

Note: Comments and course descriptors have been reproduced exactly as written on the appointment request forms. *Early Childhood Education, ${ }^{* *}$ Human Services

Another student's trajectory seems to go in the opposite direction (see Table 2). In keeping with our overall quantitative finding (discussed below) that over the course of their degrees, students' requests for appointments decreased in length, this student writes less and less in the request box and also engages in more deficit discourses than they began with. This was again incongruent with the nature of the actual content of the consultation, as indicated in the consultants' notes.

To analyze this discrepancy quantitatively, we drew from Pennebaker's (2011) distinction between content and function words, to measure only the content words to compare their incidence in both student requests and consultant reports. The table reveals that, in the top ten content words, only two ("Paper" and "Write/writing") were shared between consultant and student"

The term "essay" has the top spot in student discourse, with evidence that it was actively avoided by consultants, where it was the 18th most common term. Faculty consultants may have wished to avoid this baggage-laden and chronically overused term (c.f. "What is an essay, Alex?" in Giltrow, 2003, p. 26) to seek out ways to refer to assignments in terms that are more closely in tune with the task at hand. Still, Roger Graves (2017) would point out that the terms of engagement consultants 
Volume 29, 2019

http://journals.sfu.ca/cjsdw

fell back on, notably "paper" and "assignment," are still "too general to indicate what genre of document students must produce" (pp. 16-17, drawing on Shaver, 2007). Similarly, Andrea Williams (2017), also drawing on Shaver's work, advises that departmental colleagues agree upon specific assignment names across their courses that are in keeping with disciplinary norms (p. 93).

While the discrepancy between student and consultant discourse evident in Table 3 could more generally indicate genre specificity, in that a request for a consultation and a report of a consultation are two different genres, we suggest that at the level of discourse-especially in the context of writing centre consultants' conscious efforts to shift student discourse in ways that empower them-there is an indication of the power of deficit discourses evident in the persistence of terms (e.g., "edit," "grammar," "APA") that reflect LOCs. Interestingly, Mackiewicz's (2018) data that compared tutor discourse in 2000 with that in 2017, isolated "comma" as one of the top two content words in each year's corpus (p. 74), as well as being the top content word in student talk in 2000 (p. 121). Its position in the latter dropped to 23 in 2017; nonetheless, Mackiewicz explains this high occurrence as evidence of LOCs in consultations, despite and in the context of a general "lore" in writing centre tutor training to focus on HOCs.

Table 3. Top ten content terms: student/consultant compared

\begin{tabular}{|c|l|c|l|c|}
\hline rank & STUDENT (1688) & $\mathbf{n = 4 2 , 8 7 3}$ & CONSULTANT (6) & $\mathbf{n = 7 6 , 9 5 1}$ \\
\hline 1 & essay & 685 & work* & \\
\hline 2 & Like & 617 & Paper & 789 \\
\hline 3 & gramm* & 583 & writ* & 739 \\
\hline 4 & paper & 559 & discuss* & 670 \\
\hline 5 & writ* & 521 & talk* & 536 \\
\hline 6 & structure & 403 & assignment & 382 \\
\hline 7 & help & 340 & cit* & 327 \\
\hline 8 & review & 327 & summar* & 308 \\
\hline 9 & edit* & 271 & research & 303 \\
\hline 10 & APA & 260 & Consultant & 216 \\
\hline
\end{tabular}


Volume 29, 2019

http://journals.sfu.ca/cjsdw

Next, we created two corpora: the first took all student requests for their first two appointments and compared to the second, their requests for their last two appointments over the four-year period. Again, we counted the top content words for each corpus to produce the following table:

Table 4. Top content terms first/last appointments compared

\begin{tabular}{|c|l|c|l|c|}
\hline rank & \multicolumn{1}{|c|}{$\begin{array}{c}\text { FIRST TWO } \\
\text { (11839) }\end{array}$} & per 10,000 & $\begin{array}{c}\text { LAST TWO } \\
\text { (9706) }\end{array}$ & per 10,000 \\
\hline 1 & writ* & 198 & gramm* & 188 \\
\hline 2 & essay & 197 & paper & 150 \\
\hline 3 & paper & 134 & essay & 137 \\
\hline 4 & gramm* & 134 & structur* & 106 \\
\hline 5 & help & 103 & review & 103 \\
\hline 6 & structur* & 90 & cit* & 91 \\
\hline 7 & review* & 81 & writ* & 88 \\
\hline 8 & edit* & 65 & help & 83 \\
\hline 9 & cit* & 60 & edit* & 73 \\
\hline
\end{tabular}

The most salient shift indicated here is that our signal term "grammar" rose to first place as the most common term over the course of students' trajectories through their programs. We also noted slightly higher lexical variation in the first two requests (1487 types) versus the latter requests (1381 types), suggesting students used a less complex vocabulary to talk about their writing as they moved through their degrees.

One more term deserves comment before we move on: "help." As indicated in Tables 3 and 4, the term was prominent in student discourse, most poignantly, for example, in the comment "I just need help." We link the high incidence of this term to the strand of scholarship on the role of women in writing pedagogy and writing centre work, and metaphors of "home" associated with writing center spaces; "home," according to McKinney (2005), is the "dominant metaphor for writing centre spaces," and "associated with upper- and middle-class White ideas of comfort, the feminine and feminism, and a refuge from the institution" (as cited in Babcock \& Thonus, 2012, p. 64). Indeed, there is a solid history of research on how women are more readily enlisted in the project of reme- 
Volume 29, 2019

http://journals.sfu.ca/cjsdw

diation (Miller, 1991), and more often hired to do writing centre work (Landry, 2016). Concurrently, they find themselves more easily interpellated as a benevolent "writing lady" (Alexander, 2005), and thus inexorably intertwined with "helping" and "nurturing" discourses in writing centres (Bermingham, 2015; McNamee \& Miley, 2017) ${ }^{5}$. It is in this context of a gendered, linguistic market that many writing centres find themselves occupying marginal spaces on university campuses, operating with contingent and expendable labour, and being more vulnerable than other areas to enforced market models of efficiency and data management.

\section{"Frequent flyer" data}

Sixty-two of 1,688 students over the period in question could be considered frequent users, in that they used the writing centre eight times or more over the course of their degree. An analysis of their records revealed that only nine of 62 (or 15\%) showed evidence of a general shift in focus from LOCs to HOCs. In contrast, 23 (or 37\%) persistently focused on LOCs from first to last visit. While this does not mean remaining users made only higher-level requests, it emphasizes that about one third did not show marked shifts from LOCs to HOCs in their written requests from first to last recorded appointment. When users' requests were compared with consultants' postconsultation reports, there was incongruence in 16 (or 26\%) cases-indicating these users' written comments regarding their appointments did not match the consultants'. Of the 25 users that showed a persistence in requesting help with LOCs from first to final visits, 13 (21\%) showed incongruence with writing centre consultant reports, revealing that in the majority of these cases, while students made frequent requests related to "grammar" and other LOCs, centre consultants' comments identified more macro-level concerns as the focus of the appointments overall. So, with these results in mind, while 25 students persisted in making LOC requests over the course of their visits, 13 of these records reveal that from the centre consultants' perspectives, HOCs were either additionally or exclusively addressed.

How might we explain incongruence between requests and consultant reports? According to Robinson (2009), some students might claim to want to focus on LOCs because they "have an impression that the surface serves as a gatekeeper for satisfying their consultants (which may, in fact, be true)" (p. 85). Robinson goes on to speculate that this tendency for some to focus on LOCs such as "grammar" might also represent a way to be much less vulnerable when asking for help: 
Volume 29, 2019

http://journals.sfu.ca/cjsdw

[I]t is a request for help with conforming to external requirements, rather than a request for help in changing how one does something. It is much easier to articulate a request for help with grammar and organization: for one, it means starting with something rather than nothing, and so it does not require the students to ask for help with a true deficiency - something they altogether cannot do. (p. 85)

It does seem reasonable that students would, in advance of their visits, look to the "requests" section as a place to set protective boundaries and/or show engagement with assumed academic community values through LOCs. In "[a] genre and move analysis of written feedback in higher education," Yelland (2011) describes the riskiness of giving (with implications for receiving) feedback and its potential as a "serious face-threatening act" (p. 225), which raises the issue of how strong a disincentive any requests about their writing, let alone those involving HOCs, might be for some users.

Another intriguing finding in this data is that 15 (or 24\% of 62) frequent users' records suggest they are focused mostly if not exclusively from first to final visit on HOCs, a pattern corroborated by writing centre consultant comments. These students did not show progression to even higher order concerns, nor regression to LOCs in their requests, but rather consistency - and with regard to their willingness to visit a place that traditionally fights the "fix-it shop” label, to use Robinson's (2009, p. 86) description, we might wonder about the reasons for these students' visits. Post-consultation reports from the writing centre consultants sometimes offered insights. One such comment, "anxious student, but seems to be getting less so as she gets familiar with all of the technologies and genres," speaks to a desire for greater confidence and familiarity serving as substantial incentivesomething Tan (2009) explores as a student's "intangible gain in the affective domain" (p. 50), while another record speaks twice of the student's strong "engagement" with her studies. In keeping with Robinson's research into the connection between students' intrinsic motivation and tendency towards a focus on HOCs, this particular user's engagement might well have been the driver behind regular sessions that replaced "fix-it" talk with macro-level explorations. Finally, another centre consultant's post-consultation report indicates, in the case of a different frequent user, the student "wants to improve her writing overall, going beyond, she says, what would keep her instructors happy" - again, another connection, perhaps, to intrinsic motivation.

A final observation related to frequent users focused on HOCs is that five (or 8\%) show evidence of having taken first or second-year, writing-intensive courses with instructors in the field of Writ- 
Volume 29, 2019

http://journals.sfu.ca/cjsdw

ing Studies who were also writing centre consultants. Of the five users identified who fit this criteria, only one used the term "grammar" in two of his/her requests, and these two incidences were connected with nursing (NURS) courses; the only LOC that periodically did appear in these users' requests involved mentions of particular citation styles (e.g., APA or MLA) alongside other HOCs (e.g., "flow" and "transitions," along with "orchestrating views" in relation to "research"; as well as "check if my ideas make sense and flow naturally"). While it would be unproductive to make claims about such a small number of user records, it is interesting to speculate on the influence rhetorical and genre approaches to academic writing instruction might have in students' subsequent coursework when compared to the records of those who had different instructional experiences in their foundational writing courses.

In sum, this qualitative data suggests that about $15 \%$ of the users demonstrate what we might regard as a shift away from deficit discourse in their requests for writing centre consultations. Another $21 \%$ show little to no deficit discourse in their requests, while $26 \%$ reveal deficit discourse, even when, from the consultants' perspective, HOCs seem to have played a role in the consultations. In the cases where a deficit discourse either partially or fully persists, psychological factors (e.g., face-saving) and situational factors (e.g., carryover from courses dominated by lowerorder discussions of writing) must be considered.

\section{Conclusion}

Our quantitative data indicates that what we are calling deficit discourses-the abundance of terms like "grammar" as signalling a focus on LOCs and remediation-increased rather than decreased overall across the four years of data. We reason that this stated desire for a focus on grammar and proofreading points to the persistence of a particular stance toward both writing and the role of writing centres in higher education.

Our qualitative data also could be said to offer support for this view, in that there were a substantial number of students whose discourse did not shift over a series of appointments. Intriguingly, a noticeable incongruence frequently appeared between various students' LOC requests and their writing centre consultants' summaries, which claimed that HOCs actually dominated these appointments. This, we reason, speaks to the discursive traction of what Robinson (2009) calls the "fix-it" perspective, even in the face of students' experience to the contrary. In other words, students' actual behaviour-without a change in their discourse-suggests a disloyalty to a remedial approach when presented with other ways of working. 
Volume 29, 2019

http://journals.sfu.ca/cjsdw

What then seems to be apparent is that asking students what they want to work on might not be very functional-or that, as a genre, it is even dysfunctional. Rather than inviting what we were hoping were newly-acquired discourses about writing, more often than not the genre actually invited the anxious repetition of old discourses. If we do look at student requests for an appointment as a genre, then, we would posit that it actually lacks functionality, because it sets up terms of engagement from discourses writing centres usually prefer to elude, and that are hard for students to shake.

We could also explain our results by saying that traditional discourses that focus on deficit and remediation speak louder on the university campus, and are being repeated by course instructors, and in rubrics (Dryer, 2013) and assignment descriptions (Griffin \& Glushko, 2016, p. 168). As others have noted, writing centres can benefit from these discourses, because they lend themselves so readily to providing justification for funding, and indeed for our very jobs. This, in turn, has implications for both the institutional positioning of writing centres in the university and more widely, the state of our discipline. Giltrow (2016) made the point that we risk the consequences of claiming too much, in the form of solving the problems of underprepared students, and raising all students' levels of participation in the research genres. Coupled with mainstream common sense ideas about correctness and grammar (c.f. Rea, 2006; Dunn, 2017), this discourse is persuasive to administrators and other stakeholders, but when discourses that define us and our work come unattached to our disciplinary foundations, as Giltrow (2016) warns, it may be "good news for a while-but there is a cost to writing studies as a discipline" (p. 20).

As long as these deficit discourses hold power, writing centres in Canada may struggle to assert themselves as both a theorized locus for interdisciplinary conversations about academic writing and an emancipatory force for change in an often-repressive linguistic market.

\section{Endnotes}

1. See Griffin, Glushko, \& Liu. (2019, pp. 1-2) for a recent overview.

2. Data used for this study included information from courses at the time identified as "English as a Second Language (ESL)." These courses would now be recognized as part of "English Language Studies (ELS)."

3. Our anecdotal evidence about nursing students contradicts a study done by Giminez (2008) in the UK. Her survey data revealed the following: "It emerged that nursing students are less used to checking the grammar of their assignments, which shows their lack of awareness of the role that 
Volume 29, 2019

http://journals.sfu.ca/cjsdw

grammar plays in their assignments, even when 'correct grammar' is part of the marking criteria, and their lack of attention to the marking criteria" (p. 161).

4. Our focus on content words here is not to say that function words are not also worthy of attention, and could be a future focus. In her study of talk about writing in a writing centre, which compars data between 2000 and 2017, Mackiewicz (2018) found salient differences in student and tutor uses of personal pronouns, for example, reflecting "the client-centered nature of the 2000 and 2017 pedagogical interactions" (68).

5. As women ourselves, we recognize this discourse in our own writing, for example in our calling the request for an appointment genre a "help request."

\section{Acknowledgements}

We would like to thank Maxina Spies for her research assistant work on this project, as well as the anonymous blind reviewers for their very useful comments on an earlier draft. Last but not least, we tip our hats to our amazing faculty colleagues whose comments pepper this data set.

\section{References}

Alexander, K. (2005). Liminal identities and institutional positioning: On becoming the writing lady in the academy. Inkshed, 22(3), 5-16.

Artemeva, N. (2011). "An engrained part of my career": The formation of a knowledge worker in the dual space of engineering knowledge and rhetorical process. Writing (in) the knowledge society. D. Starke-Meyerring, A. Paré, N. Artemeva, M. Horne, \& L. Yousoubova (Eds). West Lafayette: Parlor Press and Fort Collins: The WAC Clearinghouse, 321-350.

Babcock, R. \& Thonus, T. (2012). Researching the writing centre: Towards an evidence-based practice. New York: Peter Lang Publishing.

Bermingham, C. (2015, May). Help wanted? A keyword analysis of how writing centre communications constitute a relational framework. Paper presented at the Canadian Association for Studies in Discourse and Writing (CASDW) conference, Congress of the Humanities and Social Sciences, Ottawa, ON.

Bourdieu, P. (1991). Language and symbolic power. Cambridge, Mass: Harvard University Press. 
Volume 29, 2019

http://journals.sfu.ca/cjsdw

Bourdieu, P. \& Passeron, J. C. (1994) Introduction: Language and the relationship to language in the teaching situation. In P. Bourdieu, J-C. Passeron, J-C., \& M. de Saint Martin (Eds.), Academic discourse. (pp. 1-34). Cambridge: Polity Press.

Cameron, D. (1995). Preface. Verbal hygiene. pp. vii-xiv. New York: Routledge.

Carino, P. (1995). Early writing centers: Toward a history. The Writing Center Journal 15(2), 103-115.

Carino, P. \& Enders, D. (2001). Does frequency of visits to the writing center increase student satisfaction? a statistical correlation study - or story. The Writing Center Journal, 22(1), 83-103.

Charney, D., Newman, J. H., \& Palmquist, M. (1995). “I'm just no good at writing”: Epistemological style and attitudes toward writing. Written Communication. 12(3), 298-329. doi: $10.1177 / 0741088395012003004$

Dryer, D. B. (2013). Scaling writing ability: A corpus-driven inquiry. Written Communication. 30(3), 3-35. doi: 10.1177/0741088312466992

Dunn, P. A. (2017). Teaching grammar improves writing. In C. E. Ball \& D. M. Loewe (Eds.), Bad ideas about writing (pp. 144-149). Retrieved from https://textbooks.lib.wvu.edu/badideas/badideasaboutwriting-book.pdf

Gill, R. (2000). Discourse analysis. In M. W. Bauer \& G. Gaskell (Eds.), Qualitative researching with text, image and sounds: A practical handbook for social research (pp. 172-190). London: Sage.

Giltrow, J. (2003). Academic writing: Reading and writing across the university. Peterborough, ON: Broadview Press.

Giltrow, J. (2016). Writing at the centre: A sketch of the Canadian history. Canadian Journal for Studies in Discourse and Writing/Rédactologie, 6, 11-24. doi: 10.31468/cjsdwr.48

Gimenez, J. (2008). Beyond the academic essay: Discipline-specific writing in nursing and midwifery. Journal of English for Academic Purposes, 7(3), 151-164. doi: 10.1016/j.jeap.2008.03.005

Graves, R. (2016). Statement on writing centres and staffing. Canadian Journal for Studies in Discourse and Writing/Rédactologie, 26, 5-10. doi: 10.31468/cjsdwr.47

Graves, R. (2017). Writing assignments across five academic programs. In R. Graves \& T. Hyland (Eds.), Writing assignments across university disciplines. (pp. 1-30). Bloomington, IN: Trafford.

Griffin, K. R. \& Glushko, T. (2016). Caught between the promise and the past: A view from the Writing Center. Composition Studies, 44(2), 167-171. Retrieved from https://searchebscohost- 
Volume 29, 2019

http://journals.sfu.ca/cjsdw

com.proxy.ufv.ca:2443/login.aspx?direct=true \&db=edsgao\&AN=edsgcl.544602385\&site=edslive

Griffin, K. R., Glushko, T. \& Liu, D. (2019). Rhetorical awareness of student writers at an HBCU: A study of reflective responses in the writing center. Praxis: A Writing Center Journal, 16(2).

Landry, D. L. (2016). Writing studies in Canada: A people's history (Unpublished doctoral dissertation). University of British Columbia, Vancouver, Canada.

Lee, I. (2004). Error correction in L2 secondary writing classroom: The case of Hong Kong. Journal of Second Language Writing, 13, 285-312. Retrieved from

http://www.fed.cuhk.edu.hk/ aflwrite/article/Lee\%20Error\%20correction\%20in\%20L2\%20s econdary\%20writing\%20classrooms.pdf

Mackiewicz, J. (2018). Writing center talk over time: A mixed-method study. New York: Routledge.

Makmillen, S., Aubé, M. \& Fitzgerald, H. (2013). Supporting Aboriginal students in academic writing: Decentring the writing centre. In J. D. Andre (Ed.), Transformations at the edge: Writing research, discourse, and pedagogy proceedings of the fifth annual conference of the Canadian Association for the Study of Discourse and Writing (pp. 44-60). Retrieved from https://casdwacr.files.wordpress.com/2013/09/final-sept-19-casdw-2013-conferenceproceedings.pdf

McNamee, K., \& Miley, M. (2017). Writing center as homeplace (A site for radical resistance). The Peer Review, 1(2). Retrieved from http://thepeerreview-iwca.org/issues/braverspaces/writing-center-as-homeplace-a-site-for-radical-resistance/

Miller, S. (1991). Textual carnivals: The politics of composition. Southern Illinois Press.

Milroy, J., \& Milroy, L. (1985). Authority in language: Approaches to language standardisation and prescription. language, education, and society. Boston MA: Routledge.

Pennebaker, J. W. (2011). The secret life of pronouns: What our words say about us. New York, NY: Bloomsbury.

Rea, J. (2006). Ideologies of language: Authority, consensus and commonsense in Canadian talk about usage (Unpublished doctoral dissertation). Simon Fraser University, Burnaby, Canada. Retrieved from summit.sfu.ca/system/files/iritems1/2863/etd2355.pdf

Robinson, H. M. (2009). Writing center philosophy and the end of basic writing: Motivation at the site of remediation and discovery. Journal of Basic Writing. 28(2). 70-92. Retrieved from https://files.eric.ed.gov/fulltext/EJ877256.pdf 
Volume 29, 2019

http://journals.sfu.ca/cjsdw

Shaughnessy, M. (1977). Errors and expectations: A guide for the teacher of basic writing. New York, NY: Oxford University-Press.

Tan, B. H. (2009). Assessing the efficacy of writing centres: A review of selected evaluation studies. Pertanika Journal of Social Sciences \& Humanities, 17(2), 47-54. Retrieved from https://core.ac.uk/download/pdf/153798306.pdf

Washington, M. C. (2014). The impact of writing assignments in business education: Toward a competitive advantage in the workplace. American Journal of Business Education, 7(3), 265-270. Retrieved from

https://proxy.ufv.ca:2443/login?url=https://search.ebscohost.com/login.aspx?direct=true \&db= eric\&AN=EJ1053622\&site=eds-live

Williams, A. (2017). Writing assignments in a life sciences department: More opportunity than motive? In R. Graves \& T. Hyland (Eds.), Writing assignments across university disciplines. (pp. 73104). Bloomington, IN: Trafford.

Yelland, C. (2011). A genre and move analysis of written feedback in higher education. Language and Literature, 20(3), 218-235. doi: 10.1177/0963947011413563 